\title{
The Identification of Fouling in Reverse Osmosis in the Treatment of Water with Petroleum Substances
}

\author{
Janina Piekutin $\mathbb{D}$
}

Citation: Piekutin, J. The

Identification of Fouling in Reverse Osmosis in the Treatment of Water with Petroleum Substances. Water 2021, 13, 1092.

https://doi.org/10.3390/w13081092

Academic Editor: Joanna Karpińska

Received: 29 March 2021

Accepted: 13 April 2021

Published: 15 April 2021

Publisher's Note: MDPI stays neutral with regard to jurisdictional claims in published maps and institutional affiliations.

Copyright: (C) 2021 by the author. Licensee MDPI, Basel, Switzerland. This article is an open access article distributed under the terms and conditions of the Creative Commons Attribution (CC BY) license (https:// creativecommons.org/licenses/by/ $4.0 /)$.
Department of Technology in Environmental Engineering, Faculty of Construction and Environmental Sciences, Bialystok University of Technology, 45A Wiejska Str., 15-351 Bialystok, Poland; j.piekutin@pb.edu.pl; Tel.: +48-85-746-96-44

\begin{abstract}
Water containing petroleum substances is very difficult to clean, and the treatment process usually consists of several stages. Despite the increasing use of integrated membrane processes to purify natural waters, including the removal of organic substances, work is underway on the search for new processes and their optimization. This paper deals with the study of the removal of petroleum hydrocarbons from the benzene, toluene, ethylbenzene, and xylene (BTEX) group by reverse osmosis and optimization. The research was conducted on surface water enriched with a fuel mixture. Then, the reverse osmosis efficiency was modeled using the constant pressure filtration model (Hermia model), which determined the most likely membrane blocking mechanism. When the membrane was operated on surface water enriched with BTEX, the blocking of the membrane was based on the $n=0$ cake mechanism. In surface water alone, the highest correlation coefficient was 0.9994 and corresponded to a temporary blocking mechanism $(n=1)$.
\end{abstract}

Keywords: surface water; BTEX; reverse osmosis; Hermia model

\section{Introduction}

The issue of the contamination of aquatic systems with petroleum products gained increasing importance because high concentrations of these contaminants were detected not only in surface waters, but also in some groundwater intakes [1-5]. The awareness of this problem resulted in the development of techniques aimed at removing oil products from the aquatic environment. There are known processes dedicated to the removal of petroleum compounds from water (e.g., ultrafiltration). However, there is no system that can ensure the efficient removal of petroleum products including benzene, ethylbenzene, toluene, xylene (i.e., ortho-, meta-, and para-xylene) (BTEX), and aliphatic hydrocarbons. The results of researchers dealing with the problem of hydrocarbons removal from water [4-8] and our own previous research indicate that it is appropriate to evaluate the effectiveness of removing BTEX and aliphatic hydrocarbons from water and to determine the mechanisms of their separation and their blocking of membranes. Various principles of the semi-empirical modeling of mass transport in the membrane are discussed in the literature [1-4,6-14]. In general, a distinction can be made between membrane-related descriptions (which are based on assumptions about the structure or quality of the membrane) and membraneindependent, purely phenomenological models. In phenomenological terms, mass transport is operated with directly measurable quantities, and the solution to the problem is to find mathematical relationships between these quantities. The obtained equations, based on generally valid laws, allow for a compact and consistent ordering of the measurement data. They are free from the physical models and hence from the errors associated with these models. The descriptions related to the membrane most often refer to concentration polarization and fouling as basic reasons for the decrease of the permeate flux $[8,9,11-17]$. Their components are used to forecast changes in efficiency and determine the regeneration time or the type of regenerative agent. 
In general, membrane fouling can be described as a reduction in membrane permeability as a result of the flow resistance appearing due to pore blocking, concentration polarization, and cake formation [3,10-14]. Membrane permeability declines due to the accumulation of foulants on the membrane surface or within the membrane pores [3,12-18]. Moreover, it has been determined that fouling mechanism depends mainly on the electrostatic interactions between particles, as well as those between particles and the membrane. On the other hand, the long-term effects of membrane fouling may lead to irreversible blockage of the membrane and a reduction in the membrane lifetime [13]. To maintain the technical and economic viability of membrane processes, membrane fouling should be kept to a minimum $[3,14,19-21]$.

Descriptions related to the operation of membrane processes most often concern optimizing the efficiency and control of contaminants deposition. There are several concepts for modeling membrane efficiency based on the analysis [6-8,13,17,18,20-25]: filtration in a nonstationary process (relaxation model), resistances, pore-blocking mechanisms in the membrane (Hermia model), critical flux, surface renewal (lamellar model), or surface modification.

The Hermia model is one of the equations found in the literature that allows determination of the mechanism of membrane blockage during filtration under constant pressure. This model takes the form of a differential equation.

\subsection{Theoretical Background}

\section{Constant Pressure Pore-Blocking Model (Hermia Model)}

To identify the fouling mechanism during the reverse osmosis process of the BTEXtype solution in water, a mathematical model describing the drop in flux over time can be used [2,6,8-10,18-21]:

The model describes the change in the efficiency of the filtration process using a two-parameter differential equation:

$$
\frac{d^{2} t}{d V^{2}}=k\left(\frac{d t}{d V}\right)^{n}
$$

where $V$ is the permeate volume, $t$ is the time of the filtration process, and $n$ and $k$ are constants characteristic of various mechanisms of capacity limitation during the filtration process under constant pressure conditions.

The model described by Equation (1) can be used as a convenient criterion for identifying various pore-blocking mechanisms in the membrane by performing tests recording the volumetric flux of the permeate over time under constant pressure conditions. It is assumed that the parameter $n$ can take four discrete values [6,22-28]:

The value $\mathrm{n}=2$ corresponds to the mechanism of complete pore blocking, in which it is assumed that all particles of the suspension are involved in blocking the pores without affecting each other. With such assumptions, a proportional relationship between the blocked surface and the permeate volume is obtained,

$$
\ln \left(\frac{1}{J}\right)=\ln \left(\frac{1}{J_{0}}\right)+k_{1}
$$

where $J$ is the permeate flux $(\mathrm{m} / \mathrm{s})$ and $J_{0}$ is the initial permeate flux $\left(\mathrm{m}^{3} \mathrm{~m}^{-2} \mathrm{~s}^{-1}\right)$.

When $\mathrm{n}=3 / 2$, blocking occurs inside the pores, the volume of which proportionately decreases the volume of the permeate. The same diameter and length of the pores are assumed here,

$$
\frac{1}{\sqrt{J}}=\frac{1}{\sqrt{J_{0}}}+k_{0} t
$$

When $\mathrm{n}=1$, there is a temporary blocking of pores, particles are deposited on particles which are already immobilized on the membrane, and therefore the probability of the 
particles reaching the pores that are not yet blocked constantly decreases with the reduction of the surface of these pores,

$$
\frac{1}{J}=\frac{J}{J_{0}}+k_{3} t
$$

When $\mathrm{n}=0$, according to the cake blocking mechanism, the filtrate flow decreases due to an increase in the resistance in the boundary layer of the membrane due to mass accumulation of the constituents retained on the membrane. The total resistance is then the sum of the resistance and the diaphragm itself. It is assumed that the cake resistances are proportional to the mass of the deposited substance.

$$
\frac{1}{J^{2}}=\frac{1}{J_{0}^{2}}+k_{4} t
$$

The constant $k_{i}$ in each case of $\mathrm{n}$ has a variable dimension to preserve the physical interpretation of the model's phenomena.

This study uses the constant pressure filtration model presented by Hermia in the form of Equation (1) and verified by Konieczny [21].

Equation (1) was supplemented with the following boundary conditions:

$$
\begin{aligned}
& \left.\mathrm{V}(\mathrm{t})\right|_{t=0}=\left.0 \mathrm{i} \frac{d V}{d t}\right|_{t=0}=F_{0} \cdot J_{0} \\
& \left.\mathrm{~V}(\mathrm{t})\right|_{t=0}=\left.0 \mathrm{i} \mathrm{V}(\mathrm{t})\right|_{t=t_{0}}=V_{0}
\end{aligned}
$$

and the values related to the dimensionless volume $(v)$ and time $(\tau)$ were introduced

$$
\tau=\frac{t}{t_{0}} ; v=\frac{V}{V_{0}}
$$

to derive the dimensionless value of the $k$-factor.

Transforming the conditions in Equation (7) into Equation (1)

$$
\frac{d^{2} \tau}{d v^{2}}=k_{n} \cdot\left(\frac{d \tau}{d v}\right)^{n}
$$

made it possible to obtain a dimensionless permeate flux defined as:

$$
j_{0}=\frac{J_{0}}{J_{s}} ; J_{s}=\frac{1}{F_{0}} \cdot \frac{V_{0}}{t_{0}}
$$

where $j_{0}$ is the dimensionless permeate flux, $F_{0}$ is the filtration surface area, $J_{S}$ is the mean flow of the filtrate related to the initial surface, $J_{0}$ is the initial filtrate flux related to the initial surface, and $V_{0}$ is the filtrate volume at time $t_{0}$.

The determined parameter $j_{0}$ (Equation (9)) makes it possible to solve Equation (1). The equation takes an explicit form and enables the definition of membrane blocking mechanisms [21,22].

\section{Materials and Methods}

The experiments were performed based on model solutions prepared using surface water which was filtered through a sand bed and then enriched with a mixture of diesel fuel and gasoline. Gasoline and diesel fuel (fuel mixture (MP)) were mixed in a 1:3 ratio and added to the surface water. The blend resulted from the amount and type of fuels sold on the domestic market in 2018-2020. The mono-aromatic hydrocarbons were selected for the study: benzene; ethylbenzene; toluene; and ortho-, meta-, and para-xylene (BTEX).

In the surface water used for MP tests, higher BTEX concentrations were used, exceeding the environmental concentrations. The adopted order of magnitude facilitated the sample preparation procedure and increased the accuracy of measurements (Tables 1 and 2). 
Table 1. Quality of model water intended for technological tests in terms of BTEX (benzene; ethylbenzene; toluene; ortho-, meta-, and para-xylene) content.

\begin{tabular}{|c|c|c|c|c|c|}
\hline \multirow{3}{*}{ Water Type } & \multirow{3}{*}{ Symbol } & \multirow{3}{*}{\multicolumn{2}{|c|}{$\begin{array}{c}\text { Absorbance }\left(\mathrm{UV}_{254}\right) \\
1 / \mathrm{cm}\end{array}$}} & \multirow{2}{*}{\multicolumn{2}{|c|}{$\begin{array}{c}\Sigma \text { इBEX } \\
\mathrm{mg} \mathrm{dm}^{-3}\end{array}$}} \\
\hline & & & & & \\
\hline & & & & Min & Max \\
\hline Surface & Water 2 & 0.097 & 0.122 & 0.000 & 1.700 \\
\hline Surface $+\mathrm{MP} *$ & Water 3 & 0.202 & 0.511 & 0.800 & 17.00 \\
\hline
\end{tabular}

Table 2. Concentrations of tested hydrocarbons in individual test series.

\begin{tabular}{cccc}
\hline \multicolumn{4}{c}{ Mono-Aromatic Hydrocarbons $\left(\mathbf{m g ~ d m}^{-3}\right)$} \\
\hline $\mathrm{C}_{6} \mathrm{H}_{6}$-benzene & series I & series II & series III \\
\hline $\mathrm{C}_{6} \mathrm{H}_{5}-\mathrm{C}_{2} \mathrm{H}_{5}$ - ethylbenzene & 0.033 & 0.326 & 1.724 \\
\hline $\mathrm{C}_{6} \mathrm{H}_{4}\left(\mathrm{CH}_{3}\right)_{2}$-m+p-xylene & 0.083 & 0.888 & 2.119 \\
\hline $\mathrm{C}_{6} \mathrm{H}_{4}\left(\mathrm{CH}_{3}\right)_{2}$-o-xylene & 0.270 & 3.960 & 5.148 \\
\hline $\mathrm{C}_{6} \mathrm{H}_{5} \mathrm{CH}_{3}$-toluene & 0.105 & 1.090 & 1.416 \\
\hline$\Sigma$ BTEX & 0.311 & 3.234 & 5.356 \\
\hline
\end{tabular}

In each research process, four different concentrations of BTEX in surface water were used while determining them in series (Table 2). Each research series was subjected to changing technological conditions for a given process. Mono-Aromatic Hydrocarbons $\left(\mathrm{mg} \mathrm{dm}{ }^{-3}\right)$.

Surface water with the addition of petroleum hydrocarbons was purified in the process of reverse osmosis ( $\mathrm{RO})$.

Technological research was carried out on an installation with an installed aromatic polyamide osmotic membrane. The working area of the membrane was $1.0 \mathrm{~m}^{2}$. The RO process was carried out at a constant temperature of $308 \mathrm{~K}$, with a transmembrane pressure (TMP) in the range of 1.0-1.25 MPa and a water recovery rate from $30 \%$ to $90 \%$ at a linear feed speed of $1.1 \mathrm{~m} / \mathrm{s}$. The process was run for $2.5 \mathrm{~h}$. During this time, the volumetric permeate flux was determined every $10 \mathrm{~min}$, and the concentration of components in the feed and permeate was determined every hour. After the end of the filtration for a given transmembrane pressure value, the installation was rinsed for 5 min with deionized water, and the permeate flux was determined. The system was cleaned in several stages, at the beginning "En Ch 016 Acid" to remove $\mathrm{CaSO}_{4}$ and $\mathrm{CaCO}_{3}$, then "En Ch 006 Basic" to eliminate microbial contamination $[5,16]$. When the efficiency decreased by $10 \%$ or the content of hydrocarbons in the treated water increased in a noticeable manner (i.e., if the differential pressure increased by $15 \%$ in relation to the reference state), then the system was rinsed several times with deionized water. To ensure the RO membrane module's correct operation, the clogging index was determined for surface water $\left(\mathrm{SDI}_{15}\right)$. During the entire research period, the index was determined eight times and ranged from 1.16 to 3.3. The number of determined indices resulted from significant fluctuations in iron concentration and color. The unit capacity of the module was checked after each step.

\subsection{Analytical Methodology}

Spectrophotometric, $\mathrm{pH}$, and conductometric determinations were performed according to the applicable standards or based on analytical methodologies commonly recognized and recommended by the scientific literature [11]. The test results presented in the paper are the average of at least three determinations performed simultaneously. 


\section{GC-MS BTEX Chromatographic Analysis}

The standard method for the determination BTEX in water is by capillary gas chromatography/mass spectrometry using headspace sampling, purge and trap capillary column gas chromatography with photoionization, and electrolytic conductivity detectors in series. Field studies can be performed with mobile mass spectrometer (GC/MS). A gas chromatograph coupled with a mass spectrometer was used in the conducted research $[5,7,12]$.

The BTEX determinations in individual samples were performed using a gas chromatograph coupled with a VARIAN 4000 mass spectrometer (Harbor City, CA, USA). Separation of analytes was carried out on a VF-5 MS column with dimensions of $30 \mathrm{~m} \times 0.25 \mathrm{~mm} \times 0.25 \mu \mathrm{m}$. The stationary phase of the column was polydimethylsiloxane with a $5 \%$ share of phenyl groups. Five hundred milliliters of the tested water was used to determine BTEX. The isolation process was carried out at room temperature $\left(20 \pm 2{ }^{\circ} \mathrm{C}\right)$ on a magnetic stirrer with rotational speed equal to about $800 \mathrm{rpm}$, using $50 \mathrm{~mL}$ of dichloromethane. After separation of the aqueous and organic layers, the eluate was transferred to volumetric flasks and dried with anhydrous sodium sulfate $\left(\mathrm{Na}_{2} \mathrm{SO}_{4}\right.$, pure for analysis). The extract was separated from the water sample and concentrated to a volume of $1.5 \mathrm{~mL}$. The concentrated extract was separated and detected on the GC-MS with the following operating parameters: dosed sample volume $1 \mu \mathrm{L}$-without dividing the carrier gas stream (in the splitless mode), dispenser temperature $250^{\circ} \mathrm{C}$, carrier gas flow $1 \mathrm{~mL} / \mathrm{min}$, initial oven temperature $40^{\circ} \mathrm{C}$, isotherm $5 \mathrm{~min}$, final oven temperature $300^{\circ} \mathrm{C}$, isotherm $20 \mathrm{~min}$, temperature rise $4{ }^{\circ} \mathrm{C} / \mathrm{min}$, transfer line temperature $230^{\circ} \mathrm{C}$, ion source temperature $180^{\circ} \mathrm{C}$, range of scanned masses $40-400 \mathrm{~m} / \mathrm{z}$. Helium with a purity of 6.0 was used as the carrier gas $[5,16]$.

\section{Results and Discussion}

Table 3 presents the results of surface water tests, with particular attention to the concentration of petroleum hydrocarbons in the samples. A significant color characterizes the tested surface water, with relatively low turbidity, a variable content of organic substances expressed as chemical oxygen demand (COD) and petroleum hydrocarbons (BTEX), and moderate salinity.

Table 3. Quality of surface water used in the research.

\begin{tabular}{|c|c|c|c|c|c|c|c|}
\hline \multirow{3}{*}{ Parameter } & \multirow{3}{*}{ Unit } & \multicolumn{5}{|c|}{ Surface Water } & \multirow{3}{*}{$\begin{array}{c}R \\
(\%)\end{array}$} \\
\hline & & \multicolumn{4}{|c|}{ Values } & \multirow{2}{*}{$\begin{array}{l}\text { Standard } \\
\text { Deviation }\end{array}$} & \\
\hline & & Min & Max & Mean & Median & & \\
\hline Color & $\begin{array}{l}\mathrm{mg} \mathrm{Pt} \\
\mathrm{dm}^{-3}\end{array}$ & 10.00 & 22.00 & 16.91 & 12.00 & 1.774 & 96.00 \\
\hline Turbidity & NTU & 0.900 & 2.000 & 1.200 & 1.30 & 0.793 & 100.0 \\
\hline Conductivity & $\mu \mathrm{S} / \mathrm{cm}$ & 360.0 & 410.0 & 379.1 & 388.0 & 21.76 & 98.00 \\
\hline $\mathrm{pH}$ & & 7.190 & 7.600 & 7.270 & 7.260 & 0.110 & \\
\hline Calcium & $\underset{\mathrm{dm}^{-3}}{\mathrm{mg} \mathrm{Ca}}$ & 79.20 & 89.51 & 83.53 & 84.10 & 2.701 & 96.00 \\
\hline Manganese & $\underset{\mathrm{dm}^{-3}}{\operatorname{mg} \mathrm{Mn}}$ & 0.020 & 0.040 & 0.017 & 0.018 & 0.052 & 84.00 \\
\hline Iron & $\begin{array}{l}\mathrm{mg} \mathrm{Fe} \\
\mathrm{dm}^{-3}\end{array}$ & 0.080 & 0.190 & 0.13 & 0.38 & 0.161 & 78.00 \\
\hline $\mathrm{COD}_{\mathrm{Mn}}$ & $\frac{\mathrm{mg} \mathrm{O}_{2}}{\mathrm{dm}^{-3}}$ & 6.600 & 14.60 & 10.53 & 10.40 & 1.965 & 92.00 \\
\hline ¿BTEX & $\mu \mathrm{g} \mathrm{dm}^{-3}$ & 0.010 & 1.700 & 0.05 & 0.05 & 0.075 & 81.00 \\
\hline
\end{tabular}

The presented values (Figure 1) result from carrying out the process at a transmembrane pressure of 1.2 MPa. In the process of BTEX removal from surface water (Figure 1), a variable retention coefficient was observed for individual hydrocarbons from the BTEX 
group, ranging from $41 \%$ to $80 \%$. The highest efficiency was obtained with benzene $72-80 \%$, the lowest for $\mathrm{m}+\mathrm{p}-\mathrm{xylene} 48-62 \%$.

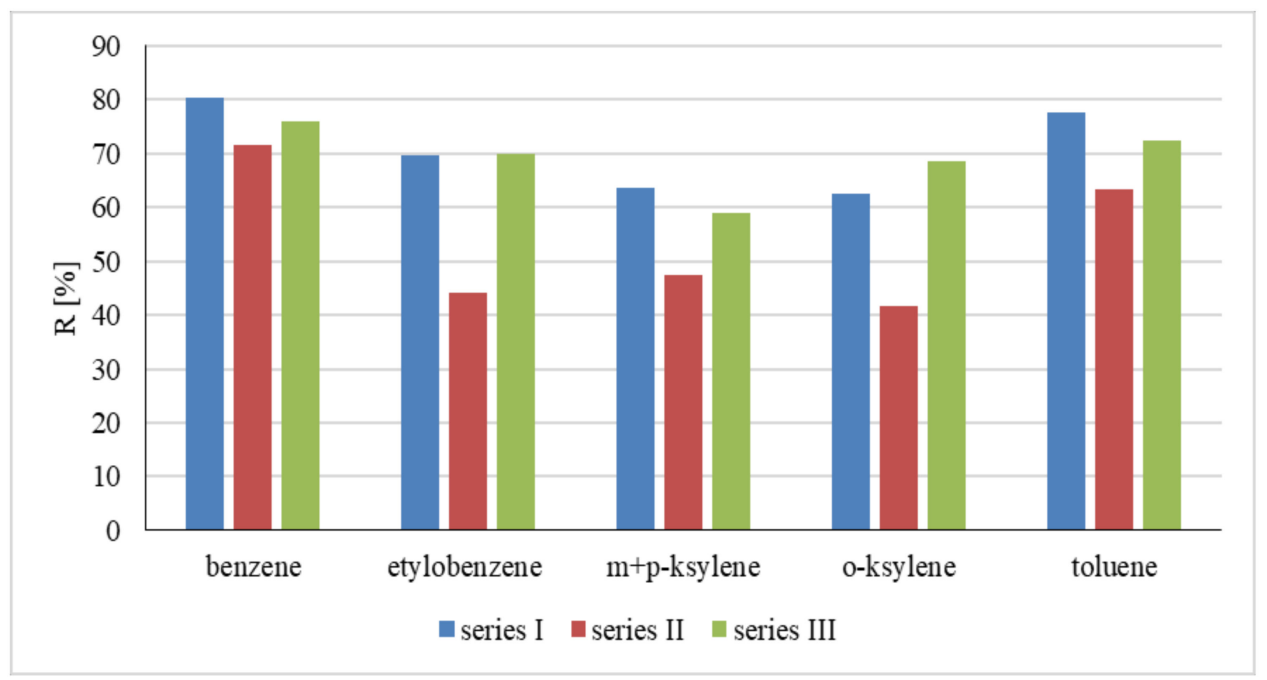

Figure 1. Change of the BTEX retention index in the individual lots at 1.2 MPa pressure.

The analysis of the obtained results (Figure 2a,b) shows the decrease of the permeate flux during the tests for each applied BTEX concentration. A rapid decrease in the size of the permeate flux is noticeable. From the beginning of the process on surface water alone and with BTEX, the membrane efficiency was from $40 \%$ to $46 \%$ (Figure 2a) of the maximum efficiency determined for pure water. At a transmembrane pressure of $1.2 \mathrm{MPa}$, the efficiency for the tested waters was higher by about $20 \%$ in comparison to the efficiency at a pressure of $1.0 \mathrm{MPa}$. The permeate flux decreased in both cases due to an increase in the thickness of the sediment layer (Figure 2). It was observed that for each applied pressure for the tested membrane, the value of volumetric permeate flux obtained for the tested water was lower than for deionized water. This can be attributed to the presence of numerous micro-contaminants and bacteria that can cause fouling in the pores of the membranes $[18,19,25-36]$.

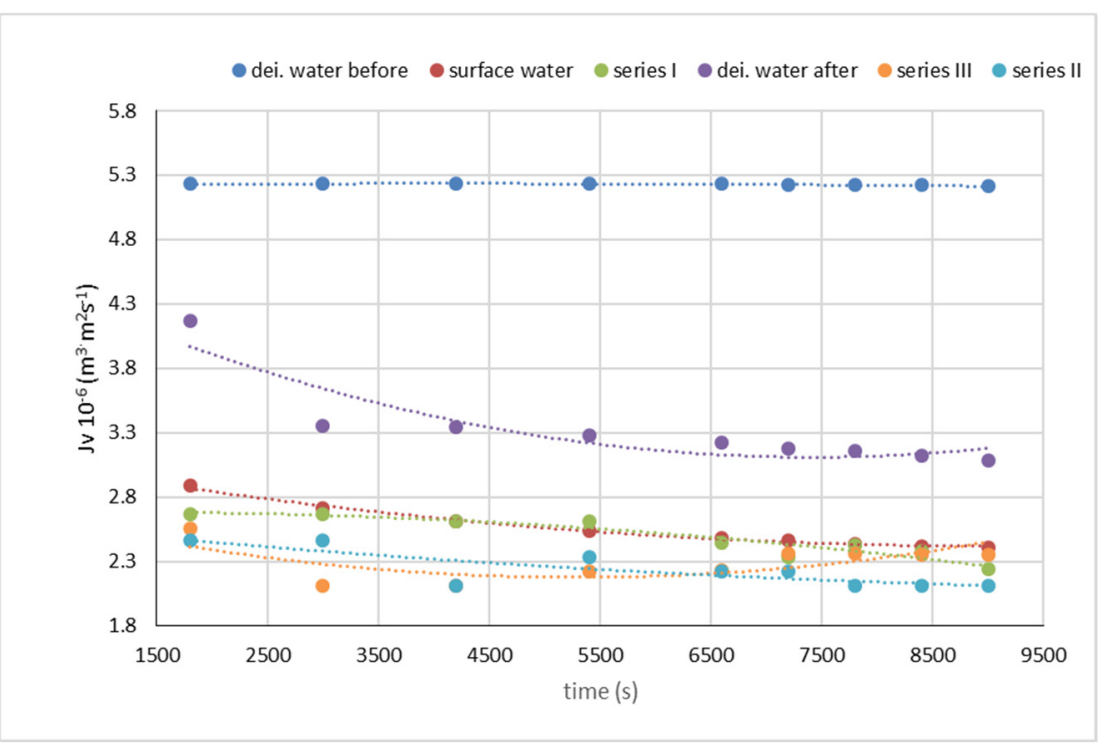

(a)

Figure 2. Cont. 


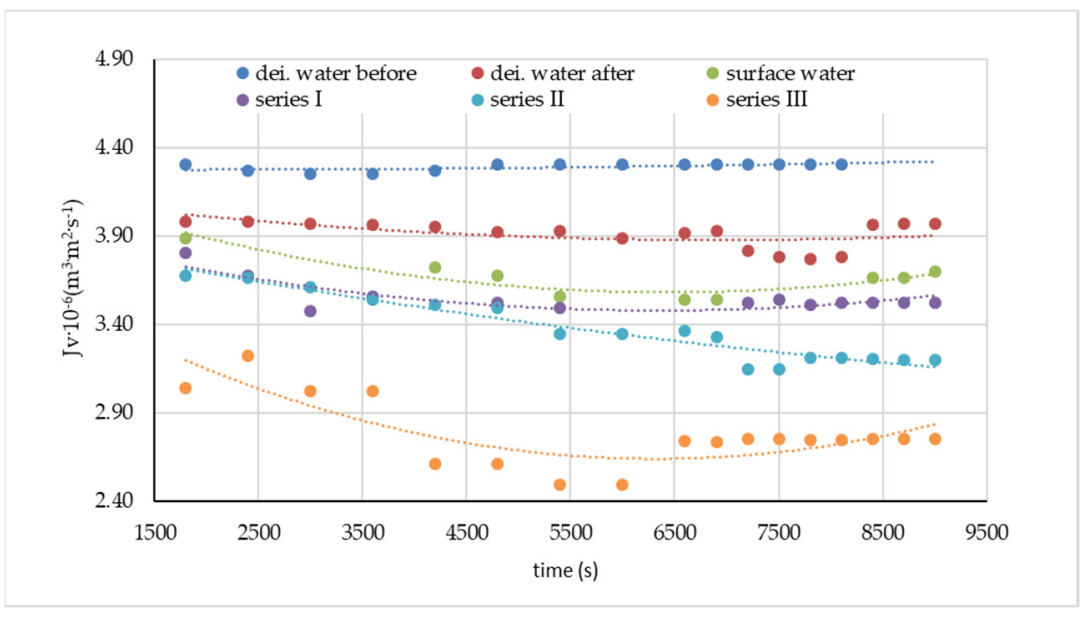

(b)

Figure 2. Change of the volumetric flux of the membrane permeate in the process of purifying surface water with BTEX: (a) pressure 1.0 $\mathrm{MPa}$ (b) pressure 1.2 $\mathrm{MPa}$, where: dei. water-deionized water, series I BTEX $0.802 \mathrm{mg} \mathrm{dm}^{-3}$, series II BTEX $9.43 \mathrm{mg} \mathrm{dm}^{-3}$, series III BTEX $15.76 \mathrm{mg} \mathrm{dm}^{-3}$.

The decrease in the efficiency of the membrane necessitated its cleaning. Regardless of the value of the driving force applied during the RO process [11,36-41], the cleaning applied restored the membrane to about $90 \%$ of its initial efficiency (Figure 2).

\section{Hermia Model}

This model requires an accurate measurement of the initial permeate flux. The dimensionless initial filtrate stream $j_{0}$ determined as a result of the experiment and the introduced dimensionless values of time $\tau$ and volume $v$ made it possible to solve the modified Hermia equation and calculate the value of the coefficient $k$ describing the process-limiting mechanism for the following values: $\mathrm{n}=0,1,3 / 2$, and 2 (Table 4 ). For individual values of the exponent $n$ (Equation (1)), we carried out a comparative analysis of the experimental curves and model curves obtained from the RO process of surface water enriched with a fuel mixture. The calculated correlation coefficient is a measure of the compliance of the curves, and its highest value indicates the best agreement between the model and the experiment. Its maximum values ranged from 0.9976 to 0.9989 in the membrane operation on surface water enriched with BTEX, which indicates the blocking of the membrane according to the $\mathrm{n}=0$ cake mechanism. This proves the lack of differentiation in BTEX concentration and the increase in resistance in the boundary layer of the membrane caused by the accumulation of a mass of the component retained on the membrane. In surface water alone, the highest correlation coefficient was 0.9994 , and corresponded to a temporary blocking mechanism $(\mathrm{n}=1)$.

On the other hand, it is difficult to assess the blocking mechanism of the membrane working on surface water alone because the values of the correlation coefficient for $n=1,3 / 2$, and 2 did not differ substantially from each other. It should be assumed that the process took place according to a mixed mechanism (i.e., some particles completely blocked the pores, and the rest settled on the surface of the membrane). The occurrence of a mixed mechanism during the process is probably related to the content of iron and calcium ions in the tested water. Data associated with the recognized membrane blocking mechanism will enable the adjustment of the control and schedule for membrane cleaning or rinsing [29-35].

The verification of the model performed using the Fisher $(\mathrm{F})$ test made it possible to assess the quality of matching of the proposed models to the data obtained as a result of the research $[10,19,36-41]$. Very high test values were obtained for the Hermia model, ranging from 665.7 to 165.7 (Table 5). There is an assumed relationship between the variables with $95 \%$ probability. 
Table 4. Correlation coefficient ( $r$ ) of fitting the experimental curve and model curves (according to Hermia) depending on the value of $n$ for the filtration process of unmodified surface water and surface water with added BTEX.

\begin{tabular}{|c|c|c|c|c|c|}
\hline \multirow[b]{2}{*}{ Water Type } & \multicolumn{5}{|c|}{ Correlation Coefficient $r$} \\
\hline & $\mathbf{n}=\mathbf{0}$ & $\mathrm{n}=\mathbf{1}$ & $\mathrm{n}=3 / 2$ & $\mathrm{n}=2$ & $\begin{array}{l}\text { Maximum Value of } \\
\text { Correlation Coefficient }\end{array}$ \\
\hline $\begin{array}{c}\text { Surface } \\
\text { Surface, Enriched with }\end{array}$ & 0.9976 & 0.9996 & 0.9994 & 0.9995 & 0.9996 \\
\hline $\begin{array}{c}\text { BTEX } \\
0.802 \mathrm{mg} \mathrm{dm}^{-3}\end{array}$ & 0.9979 & 0.9887 & 0.9842 & 0.9754 & 0.9979 \\
\hline $\begin{array}{c}\text { Surface, Enriched with } \\
\text { BTEX } \\
9.49 \mathrm{mg} \mathrm{dm}^{-3}\end{array}$ & 0.9988 & 0.9868 & 0.9925 & 0.9807 & 0.9988 \\
\hline $\begin{array}{c}\text { Surface, Enriched with } \\
\text { BTEX } \\
15.76 \mathrm{mg} \mathrm{dm}^{-3}\end{array}$ & 0.9989 & 0.9985 & 0.9983 & 0.9955 & 0.9989 \\
\hline
\end{tabular}

Table 5. Correlation coefficients obtained for the applied model relating to the experimental data and the obtained values of the significance level using the Fisher's test.

\begin{tabular}{ccc}
\hline Water Type & Correlation Coefficient $\mathbf{r}$ & Fisher's Test Value \\
\cline { 2 - 3 } & Hermia Model & $\mathbf{F}_{\mathbf{H}}$ \\
\hline Surface, BTEX & 0.9999 & 665.70 \\
$0.802 \mathrm{mg} \mathrm{dm}^{-3}$ & & \\
Surface, BTEX $_{9.49 \mathrm{mg} \mathrm{dm}^{-3}}$ & 0.9998 & 332.30 \\
Surface, BTEX $_{15.76 \text { mg dm }^{-3}}$ & 0.9999 & 665.70 \\
Surface & 0.9996 & 165.70 \\
\hline
\end{tabular}

\section{Conclusions}

This paper presents a comprehensive analysis of the behavior of a polyamide membrane in the process of reverse osmosis during the treatment of surface water containing BTEX. Based on the obtained experimental results and theoretical analysis, the following conclusions can be drawn:

1. The model developed by J. Hermia made it possible to determine the pore blocking mechanisms for the membrane during surface and surface water treatment with BTEX. The concentration of BTEX in the water did not affect the blocking mechanism of the diaphragm. The research confirmed a good agreement between the experimental and theoretical results.

2. Based on the comparison of the results obtained experimentally with the results obtained based on the Hermia model analysis, we showed that the dominant membrane blocking mechanism in the studied process was the formation of a filter cake.

3. This means that polyamide membrane fouling by BTEX and mono-aromatic hydrocarbons in surface water followed a sequence of mechanisms with an initial flux decline due to an internal pore blocking mechanism, followed by complete pore blocking with subsequent intermediate pore blocking. Finally, it should be pointed out that both resistance-in-series analysis as well as fouling mechanism identification led to consistent conclusions: the membrane fouling was of external type; the two identified pore blocking mechanisms (complete and intermediate) were also external types.

4. The fouling of the membrane was of the external type; we identified two pore blocking mechanisms ( $\mathrm{n}=0$, cake blocking; and $\mathrm{n}=1$, temporary blocking). 
Funding: The research was carried out as part of research work no. WZ/WB-IIŚ/2/2021 at the Bialystok University of Technology and financed from a subsidy provided by the Ministry of Science and Higher Education.

Institutional Review Board Statement: Not applicable.

Informed Consent Statement: Not applicable.

Data Availability Statement: Not applicable.

Conflicts of Interest: The author declares no conflict of interest.

\section{References}

1. Mohammadi, T.; Kazemimoghadam, M.; Saadabadi, M. Modeling of membrane fouling and flux decline in reverse osmosis during separation of oil in water emulsions. Desalination 2003, 157, 369-375. [CrossRef]

2. Kargol, A. A mechanistic model of transport processes in porous membranes generated by osmotic and hydrostatic pressure. J. Membr. Sci. 2001, 191, 61-69. [CrossRef]

3. Cwirko, K.; Tomczak, E.; Szaniawska, D. Membrane fouling in the ultrafiltration of water-protein-sodium chloride model systems. Chem. Process. Eng. 2018, 39, 185-196.

4. Yeit, H.T.; Zhong, Z.W.; Mohd, S.T.; Abdul, W.M. Fouling behaviours of two stages microalgae/membrane filtration system applied to palm oil mill effluent treatment. Membr. Water Treat. 2018, 9, 373-383.

5. Piekutin, J.; Skoczko, I. Use of stripping tower and reverse osmosis in removal of petroleum hydrocarbons from water. Desalination Water Treat. 2013, 52, 3714-3718. [CrossRef]

6. Hermia, J. Constant pressure blocking filtration laws. Inst. Chem. Eng. 1982, 60, 183-187.

7. Liang, S.; Lian, T.; Jian, Z.; Xuan, Z.; Shipeng, S.; Yan, W. Developing high-performance thin-film composite forward osmosis membranes by various tertiary amine catalysts for desalination. Adv. Compos. Hybrid. Mater. 2019, 2, 51-69.

8. Konieczny, K.; Rajca, M.; Bodzek, M.; Gambołyś, B. Influence of NOM properties on the fouling of ultrafiltration membranes. Environ. Pollut. 2008, 30, 3-8.

9. Mielczarek, K.; Bohdziewicz, J. Performance prediction of ultrafiltration Treatment of post-process coke wastewater based on the assumptions of hydraulic filtration resistance model. Arch. Environ. Prot. 2011, 37, 107-118.

10. Szaniawska, D.; Kuca, M. Fouling of ceramic membranes in the ultrafiltration process of protein and sodium chloride solutions. Inż. Ap. Chem. 2010, 49, 109-110.

11. Piekutin, J. Estimate of possibilities removal of selected nitrogen forms from infiltration water and optimization of reversed osmosis system. ECE 2008, 15, 9-16.

12. Guo, J.; Bao, H.; Zhang, Y.; Shen, X.; Kim, J.K.; Ma, J.; Shao, L. Unravelling intercalation-regulated nanoconfinement for durably ultrafast sieving graphene oxide membranes. J. Membr. Sci. 2021, 619, 118791. [CrossRef]

13. Lee, S.; Lueptow, R.M. Rotating reverse osmosis: A dynamic model for flux and rejection. J. Membr. Sci. 2001, 192, 129-143. [CrossRef]

14. Konieczny, K.; Rafa, J. Modeling of the membrane filtration process of natural waters. Pol. J. Environ. Stud. 2000, 9, 57-64.

15. Jamal, K.; Khan, M.A.; Kamil, M. Mathematical modeling of reverse osmosis systems. Desalination 2004, 160, 29-42. [CrossRef]

16. Setareh, H.; Mehdi, A.; Hamed, J. Investigation of Fouling Mechanisms Using Surface Morphology and Physicochemical Membrane Features. Chem. Eng. Technol. 2019, 42, 1310-1320.

17. Salahi, A.; Abbasi, M.; Mohammadi, T. Permeate flux decline during UF of oily wastewater: Experimental and modeling. Desalination 2010, 251, 153-160. [CrossRef]

18. Piekutin, J.; Skoczko, I.; Ignatowicz, K. Use of integrated process of petroleum removal from water. Desalination Water 2016, 57, 1593-1597. [CrossRef]

19. Chang, E.E.; Yang, S.Y.; Huang, C.P.; Liang, C.H.; Chiang, P.C. Assessing the fouling mechanisms of high-pressure nanofiltration membrane using the modified Hermia model and the resistance-in-series model. Sep. Purif. Technol. 2011, 79, 329-336. [CrossRef]

20. Shalana, L.B.; Kathleen, M.L.; Sherri, L.M. Evaluation of Ozone Pretreatment on Flux Parameters of Reverse Osmosis for Surface Water Treatment. Ozone Sci. Eng. 2008, 30, 152-164.

21. Konieczny, K. Ultrafiltration and microfiltration in water treatment for municipal purposes. SJSUTST 2002, 42, 36-44, [In Polish].

22. Razi, B.; Aroujalian, A.; Fathizadeh, M. Modeling of fouling layer deposition in cross-flow microfiltration durint tomato juice clarification. Food Bioprod. Process. 2012, 90, 841-848. [CrossRef]

23. Haigang, L.; Huanjin Xia, H.; Yingxin, M. Modeling organic fouling of reverse osmosis membrane: From adsorption to fouling layer formation. Desalination 2016, 386, 25-31.

24. ASTM. Standard Test Method for Silt Density Index (SDI) of Water, in Designation: D 4189-95 (Reapproved 2002); ASTM International: West Conshohocken, PA, USA, 2002.

25. Li, Q.; Elimelech, M. Organic fouling and chemical cleaning of nanofiltration membranes: Measurements and mechanisms. Environ. Sci. Technol. 2004, 38, 4683-4693. [CrossRef]

26. Bodzek, M.; Konieczny, K. Membrane Techniques in the Removal of Inorganic Anionic Micropollutants from Water Environment State of the Art. Arch. Environ. Prot. 2011, 37, 15-22. 
27. Sioutopoulos, D.C.; Karabelas, A.J. Correlation of organic fouling resistances in RO and UF membrane filtration under constant flux and constant pressure. J. Membr. Sci. 2012, 34, 407-408. [CrossRef]

28. Bellona, C.; Drewes, J.E.; Xu, P.; Amy, G. Factors affecting the rejection of organic solutes during NF/RO treat;ment-A literature review. Water Res. 2004, 38, 2795. [CrossRef]

29. Wenten, I.G.; Khoiruddin, M. Reverse osmosis applications: Prospect and challenges. Desalination 2016, 391, 112-125. [CrossRef]

30. Yorgun, M.S.; Balcioglu, I.A.; Saygin, O. Performance comparison of ultrafiltration, nanofiltration and reverse osmosis on whey treatment. Desalination 2008, 229, 204-216. [CrossRef]

31. Bird, M.R.; Bartlett, M. Measuring and modeling flux recovery during the chemical cleaning of MF membranes for the processing of whey protein concentrate. J. Food Eng. 2002, 53, 143-152. [CrossRef]

32. Chen, K.L.; Song, L.; Ong, S.L.; Ng, W.J. The development of membrane fouling in full-scale RO processes. J. Membr. Sci. 2004, 232, 63-72. [CrossRef]

33. Košutić, K.; Kunst, B. RO and NF membrane fouling and cleaning and pore size distribution variations. Desalination 2002, 150, 113-120. [CrossRef]

34. Amiri, M.C.; Samiei, M. Enhancing permeate flux in a RO plant by controlling membrane fouling. Desalination 2007, 207, 361-369. [CrossRef]

35. Ruiz-García, A.; Melián-Martel, N.; Nuez, I. Short Review on Predicting Fouling in RO desalination. Membranes 2017, 7, 62. [CrossRef]

36. Jepsen, K.L.; Bram, M.V.; Pedersen, S.; Yang, Z. Membrane Fouling for Produced Water Treatment: A Review Study from a Process Control Perspective. Water 2018, 10, 847. [CrossRef]

37. Kostogloua, M.; Karabelasb, A.J. A mathematical study of the evolution of fouling and operating parameters throughout membrane sheets comprising spiral wound modules. Chem. Eng. J. 2012, 187, 222-231. [CrossRef]

38. Pascuala, X.; Gub, H.; Bartmanb, A.R.; Zhub, A.; Rahardiantob, A.; Giralta, J.; Ralloc, R.; Christofidesb, P.D.; Cohenb, Y. Datadriven models of steady state and transient operations of spiral-wound RO plant. Desalination 2013, 316, 154-161. [CrossRef]

39. Weinrich, L.; Haas, C.N.; LeChevallier, M.W. Recent advances in measuring and modeling reverse osmosis membrane fouling in seawater desalination: A review. J. Water Reuse Desalination 2013, 3, 85-101. [CrossRef]

40. Hadadian, Z.; Zahmatkesh, S.; Ansari, M.; Haghighi, A.; Moghimipour, E. Mathematical and experimental modeling of reverse osmosis (RO) process. Sep. Technol. Thermodyn. 2021, 38, 366-379.

41. Xianhui, L.; Danyan, Y.; Genghong, A.; Dawei, J.; Jianxin, L. Fouling and Cleaning of Reverse Osmosis Membranes duing Municipal Tap Water Treatment on a Pilot-Scale Plant. J. Water Sustain. 2011, 1, 139-151. 